\title{
Comunicação
}

[Communication]

\section{Toxoplasma gondii and Neospora caninum serological status of different canine populations from Uberlândia, Minas Gerais}

\author{
[Reatividade sorológica para Toxoplasma gondii $e$ Neospora caninum em diferentes \\ populações caninas na cidade de Uberlândia, $M G]$
}

\author{
T.W.P. Mineo ${ }^{1}$, D.A.O. Silva ${ }^{2}$, K. Näslund ${ }^{3}$, C. Björkman ${ }^{3}$, A. Uggla ${ }^{3}$, J.R. Mineo ${ }^{2 *}$ \\ ${ }^{1}$ Faculdade de Ciências Agrárias e Veterinárias da UNESP - Jaboticabal \\ ${ }^{2}$ Instituto de Ciências Biomédicas - Universidade Federal de Uberlândia \\ Campus Umuarama \\ Av. Pará, $\mathrm{n}^{\circ} 1720$ \\ 38400-902 - Uberlândia, MG \\ ${ }^{3}$ Swedish University of Agricultural Sciences, Uppsala, Sweden
}

Toxoplasma gondii and Neospora caninum are two intracellular protozoan parasites, which share both morphologic and biologic similarities. Antigenically, $N$. caninum is distinct from $T$. gondii, and there is essentially no cross-reactivity in serological assays (Dubey, 1993; Björkman, Uggla, 1999).

T. gondii infection is common in dogs as demonstrated by seroepidemiological studies in different parts of the world, with prevalences ranging from 20 to $91 \%$ (Björkman et al., 1994b; Cabral et al., 1998). Clinical toxoplasmosis is rare in dogs, but may occasionally be found in puppies affected by congenital infection, in dogs with impaired immune system, or associated with concomitant infections, such as canine distemper virus (Dubey et al., 1989).

McAllister et al. (1998) showed that dogs are definitive hosts for $N$. caninum. Serological surveys performed in the past 12 years indicate that the parasite is spread worldwide, with prevalences ranging from 0 to $31 \%$ (Lindsay, Dubey, 2000). Clinical neosporosis is mainly seen in young dogs following vertical transmission (Wouda et al., 1995; Barber, Trees, 1996). Clinical signs are characterized by neuromuscular disorders due to dissemination of the parasite in the central nervous system and muscular tissues (Lindsay, Dubey, 2000).

The aim of this study was to investigate the serologic profile of dogs to $T$. gondii and $N$. caninum antigen exposure in the city of Uberlândia, Minas Gerais, and to compare the seroprevalence in different groups of dogs in relation to their origin and living conditions.

A total of 369 serum samples was obtained from three groups of dogs from the city of Uberlândia. All samples were collected in January 2001 and originated from (A) the Veterinary Hospital of the Federal University of Uberlândia (HV-UFU), which supplied 213 sera, (B) private veterinary clinics (PVC) from different parts of the city (62 sera), and (C) the Center for Zoonosis Control of Uberlândia (CCZU), which provided serum samples from 94 stray dogs captured by their daily collecting service. The dogs were from various breeds, sex and ages. The serum samples obtained from groups A and B were collected for diagnostic hematological analyses and all sera were stored at $-20^{\circ} \mathrm{C}$ until analyzed serologically, in July of the same year. The procedures were performed according to the Ethical Principles in Animal Research adopted by the Brazilian College of Animal Experimentation.

Recebido para publicação em 24 de fevereiro de 2003

Recebido para publicação, após modificações, em 1 de setembro de 2003

*Autor para correspondência

E-mail: jrmineo@ufu.br 
An indirect immunoenzymatic test was carried out for the detection of $\operatorname{IgG}$ antibodies to $T$. gondii as described (Mineo et al., 2001) with some modifications. Briefly, polystyrene microtiter plates were coated with $T$. gondii soluble antigen $(10 \mu \mathrm{g} / \mathrm{ml})$ and incubated with the serum samples diluted 1:64 in phosphate buffered saline with $0.05 \%$ tween 20 (PBS-T), $\mathrm{pH} 7.2$, and 5\% skimmed milk. A peroxidaselabeled protein $\mathrm{A}^{1}$ diluted 1:25,000 was used as secondary antibody. The reaction was revealed by the addition of $\mathrm{H}_{2} \mathrm{O}_{2}$ and ophenylenediamine (OPD). The optical density (OD) was read at $492 \mathrm{~nm}$ using a Titertek Multiskan Plus spectrophotometer ${ }^{2}$.

An Iscom-ELISA was used to analyze the serum samples for the presence of $\operatorname{IgG}$ antibodies to Neospora caninum as described by Björkman et al. (1994b). Polystyrene microtiter plates were coated with $N$. caninum antigens incorporated into iscoms (immuno-stimulating complexes). The samples were analyzed in 1:100 dilution, in parallel with control sera. The secondary antibodies utilized were a monoclonal antibody directed to $\operatorname{dog} \mathrm{IgG}^{3}$ and a rabbit anti-mouse IgG labeled with horseradish peroxidase ${ }^{4}$. After incubations and washes, the plates were incubated with enzymatic substrate consisting of citrate buffer containing TMB and $\mathrm{H}_{2} \mathrm{O}_{2}$. Absorbance values were read at $450 \mathrm{~nm}$ using a Labsystem Multiskan Plus microplate reader ${ }^{5}$.

The cut-off for a positive test was determined as the mean OD for the negative control plus five standard deviations. Antibody titers were arbitrarily expressed as ELISA indexes (EI), according to the following formula: $\mathrm{EI}=$

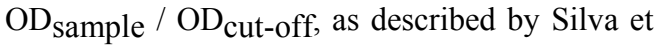
al. (2002). EI > 1.0 was considered as a positive result.

The percentages of seropositivity found in each group were compared using the differences between two proportions by $\mathrm{Z}$ statistic. Values of $\mathrm{P}<0.05$ were considered as statistically significant.

\footnotetext{
${ }^{1}$ Sigma, St. Louis, USA

${ }^{2}$ Thermo Labsystems, Helsinki, Finland

${ }^{3}$ Svanova Biotech, Uppsala, Sweden

${ }^{4}$ Dako AS, Copenhagen, Denmark

${ }^{5}$ Labsystems AB, Stockholm, Sweden
}

As demonstrated in Table 1, these results showed a lower frequency of antibodies to $T$. gondii $(30.3 \%)$ as compared to $53 \%$ of positive animals found in a previous seroepidemiological survey in the city (Cabral et al., 1998). Studies from other cities of Brazil, such as Londrina (Navarro et al., 1997) and Belo Horizonte (Guimarães et al., 1992) showed $24 \%$ and $47 \%$ seropositive dogs, respectively. These differences may be due to regional characteristics, different serological assays applied and diverse cut-off titers adopted in each laboratory.

For $N$. caninum, these results with positivity rates of $9.2 \%$ were slightly higher than those found in studies performed in some other parts of the world, such as in the USA (7\%) (Cheadle et al., 1999). In other countries, such as Sweden, considerably lower prevalences $(0.5 \%)$ have been recorded (Björkman et al., 1994b). In the present study, $5.7 \%$ of the dogs tested were seropositive to both $T$. gondii and $N$. caninum, and the CCZU group showed the highest coinfection frequency. Interestingly, there was only one animal seropositive to both parasites in the PVC group, whereas positivity only to Toxoplasma was higher than unique positivity to Neospora in all groups. In a previous survey including dogs presented at the HV-UFU with clinical signs that could be due to both infections, Mineo et al. (2001) found 36\% of 163 studied dogs seropositive to T. gondii, $7 \%$ positive to $N$. caninum only, and $3 \%$ to both parasites. A similar survey in Kansas, USA, revealed a seropositivity rate of $25 \%$ to $T$. gondii, $2 \%$ to Neospora and $1 \%$ to both parasites (Lindsay et al., 1990).

When comparing the seropositivity among the different groups of dogs studied, the prevalence of antibodies to $T$. gondii was consistently higher than that of $N$. caninum. In addition, $T$. gondii infection was significantly more common in the CCZU group (46.8\%) as compared to the HVUFU (26.8\%; $\mathrm{P}<0.001)$ and PVC $(17.7 \%$; $\mathrm{P}<0.001)$ groups. On the other hand, there was no significant difference in the percentage of animals seropositive to $N$. caninum in the different groups analyzed, although a similar increasing seropositivity profile was found for dogs when their living conditions and veterinary assistance were impaired. Co-infection with both parasites was more common in dogs from the CCZU (10.6\%) and HV-UFU (4.7\%) groups as 
compared to the PVC group (1.6\%), although a statistically significant difference was found only between the CCZU and PVC groups $(\mathrm{P}=$ $0.0329)$, with borderline values $(\mathrm{P}=0.0543)$ found between the CCZU and HV-UFU groups.
The co-infection by both parasites has never been described as a clinical case, but it could worsen the clinical signs of the affected dog, considering the pathogenesis of both agents.

Table 1. Seropositivity by ELISA to Toxoplasma gondii and Neospora caninum IgG in three different groups of dogs in Uberlândia, MG, Brazil, in 2001

\begin{tabular}{|c|c|c|c|c|c|c|c|}
\hline \multirow[b]{2}{*}{$\begin{array}{l}\text { Origin of } \\
\text { dogs }\end{array}$} & \multirow[b]{2}{*}{$\begin{array}{c}\text { Number of } \\
\text { serum samples }\end{array}$} & \multicolumn{6}{|c|}{ Seropositivity } \\
\hline & & $\begin{array}{c}\text { Toxoplasma } \\
\text { gondii }\end{array}$ & $\%$ & $\begin{array}{l}\text { Neospora } \\
\text { caninum }\end{array}$ & $\%$ & $\begin{array}{c}\text { Both } \\
\text { Parasites }\end{array}$ & $\%$ \\
\hline PVC & 62 & 11 & 17.7 & 3 & 4.8 & 1 & 1.6 \\
\hline HV-UFU & 213 & 57 & 26.8 & 19 & 8.9 & 10 & 4.7 \\
\hline CCZU & 94 & 44 & $46.8^{* *}$ & 12 & 12.8 & 10 & $10.6^{*}$ \\
\hline Total & 369 & 112 & 30.3 & 34 & 9.2 & 21 & 5.7 \\
\hline
\end{tabular}

* $\mathrm{P}<0.05$ (in relation to $\mathrm{PVC}$ group); ${ }^{* *} \mathrm{P}<0.001$ (in relation to HV-UFU and PVC groups); PVC: private veterinary clinics; HVUFU: Veterinary Hospital of the Federal University of Uberlândia; CCZU: Center for Zoonosis Control of Uberlândia.

These results suggest that stray dogs are likely to be in closer contact with risk factors to $T$. gondii infection, such as rodents and contaminated cat feces. We may speculate that this difference could be associated to social patterns, where the pet owner with higher economic status can afford better quality and quantity of food care for its dog, whereas those who are not so well off tend to feed their animals with leftovers of meals and scraps of raw meat. It is known that stray dogs are under constant exposure to risk factors to both parasites, although this exposure did not seem to make any significant differences in seropositivity to $N$. caninum in the different groups. This may be explained by the still insufficient information about the parasite's life cycle and a possible reduced number of $N$. caninum oocysts shed by dogs in comparison with $T$. gondii oocysts shed by cats. In this study, increasing rates of seropositivity were observed for both parasites, but especially $T$. gondii, according to the pattern of animal attendance level in the different groups of dogs studied, with the PVC group showing the lowest and the CCZU the highest antibody rates. It can be concluded that seropositivity to $T$. gondii and $N$. caninum in the canine populations studied seems to be influenced by the origin and living conditions of these animals.

Keywords: dog, serum profile, Toxoplasma gondii, Neospora caninum

\section{RESUMO}

Este trabalho teve como objetivo analisar a ocorrência de anticorpos contra Toxoplasma gondii $e$ Neospora caninum em cães da cidade de Uberlândia, MG. As taxas de reatividade sorológica dos animais frente a esses parasitos foram comparadas em relação à sua origem e condições de vida. Um total de 369 amostras de soro canino foi obtido de três grupos de cães: (A) 213 pacientes do Hospital Veterinário da Universidade Federal de Uberlândia, (B) 62 pacientes de clínicas veterinárias particulares da cidade e (C) 94 cães errantes da cidade. As amostras foram analisadas para a presença de anticorpos contra os parasitos por meio de ELISA. Os resultados mostraram soropositividades de $30,3 \%$ para $\mathrm{T}$. gondii, 9,2\% para $\mathrm{N}$. caninum e 5,7\% para ambos os parasitos. O grupo de cães errantes apresentou maior taxa de prevalência de anticorpos para os dois parasitos estudados. Pode-se concluir que as taxas de soropositividades para $\mathrm{T}$. gondii e $\mathrm{N}$. caninum nas populações caninas estudadas parecem ser fortemente influenciadas por suas origens e condições de vida.

Palavras-chave: cão, perfil sorológico, Toxoplasma gondii, Neospora caninum 


\section{ACKNOWLEDGMENTS}

We thank Dr. Adalberto Pajuaba Neto from the Center for Zoonosis Control of Uberlândia, for the stray dog serum samples and Professor Antônio Vicente Mundim for the serum samples that came from hematological routine of the Veterinary Hospital from the Federal University of Uberlândia, Minas Gerais, Brazil. This study was financially supported by FAPEMIG, CNPq, and the Swedish Council for Forestry and Agricultural Research.

\section{REFERENCES}

BARBER, J.S.; TREES, A.J. Clinical aspects of 27 cases of neosporosis in dogs. Vet. Rec., v.139, p.439-443, 1996.

BJÖRKMAN, C.; LUNDÉN, A.; HOLMDAHL, $\mathrm{J}$. et al. Neospora caninum in dogs: detection of antibodies by ELISA using an iscom antigen. Parasit. Immunol., v.16, p.643-648, 1994a.

BJÖRKMAN, C.; LUNDÉN, A.; UGGLA, A. Prevalence of antibodies to Neospora caninum and Toxoplasma gondii in Swedish dogs. Acta Vet. Scand., v.35, p.445-447, 1994b.

BJÖRKMAN, C.; UGGLA, A. Serological diagnosis of Neospora caninum infection. Int. J. Parasitol., p.29, p.1497-1507, 1999.

CABRAL, D.D.; SILVA, D.A.O.; MINEO, J.R. et al. Frequency of anti-Toxoplasma gondii antibodies in apparently healthy dogs of the city of Uberlândia - MG. Rev. Bras. Parasitol. Vet., v.7, p.87-90, 1998.

CHEADLE, M.A.; LINDSAY, D.S.; BLAGBURN, B.L. Prevalence of antibodies to Neospora caninum in dogs. Vet. Parasitol., v.85, p.325-330, 1999.

DUBEY, J.P. Toxoplasma, Neospora, Sarcocystis, and other tissue cyst-forming coccidia of humans and animals. In: KREIER, J.P. (Ed.). 6.ed. Parasitic protozoa. San Diego: Academic, 1993. p.385.
DUBEY, J.P.; CARPENTER, J.L.; TOPPER, M.J. et al. Fatal toxoplasmosis in dogs. J. Am. Anim. Hosp. Assoc., v.25, p.659-664, 1989.

GUIMARÃES, A.M.; RIBEIRO, M.F.B.; LIMA, J.D. et al. Frequency of antibodies to Toxoplasma gondii in dogs from Belo Horizonte, Minas Gerais. Arq. Bras. Med. Vet. Zootec., v.44, p.67-68, 1992.

LINDSAY, D.S.; DUBEY, J.P. Canine neosporosis. J. Vet. Parasitol., v.14, p.1-11, 2000 .

LINDSAY, D.S.; DUBEY, J.P.; UPTON, S.J. et al. Serological prevalence of Neospora caninum and Toxoplasma gondii in dogs from Kansas. $J$. Helminthol. Soc. Washington, v.57, p.86-88, 1990.

McALLISTER, M.M.; DUBEY, J.P.; LINDSAY, D.S. et al. Dogs are definitive hosts of Neospora caninum. Int. J. Parasitol., v.28, p.1473-1478, 1998.

MINEO, T.W.P.; SILVA, D.A.O.; COSTA, G.H.N. et al. Detection of IgG antibodies to Neospora caninum and Toxoplasma gondii in dogs examined in a veterinary hospital from Brazil. Vet. Parasitol., v.98, p.239-245, 2001.

NAVARRO, I.T.; FREIRE, R.L.; VIDOTTO, O. et al. Comparison of the use of sera and plasma for detecting antibodies against Toxoplasma gondii by indirect immunofluorescence assay in dogs seen at the State University of Londrina Veterinary Hospital (Paraná, Brazil) in 1996. Semina, v.18, p.15-21, 1997.

SILVA, D.A.O.; SILVA, N.M.; MINEO, T.W.P. et al. Heterologous antibodies to evaluate the kinetics of the humoral immune response in dogs experimentally infected with Toxoplasma gondii RH strain. Vet. Parasitol., v.107, p.181-195, 2002.

WOUDA, W.; DE JONG, J.K.; VAN KNAPEN, F. et al. Neospora caninum as a cause of paralysis in littermate pups. Europ. J. Comp. Anim. Pract., v.5, p.21-26, 1995. 